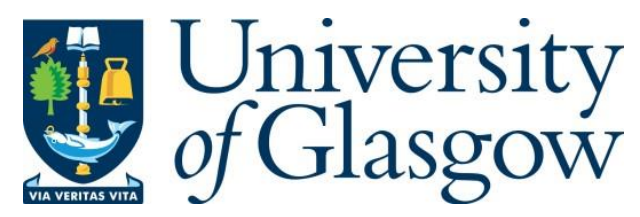

Wilson, F. (2021) Learning with the devil: mentoring and advocates. Personnel Review, (doi: 10.1108/PR-08-2020-0649).

There may be differences between this version and the published version. You are advised to consult the publisher's version if you wish to cite from it.

$\underline{\text { http://eprints.gla.ac.uk/246706/ }}$

Deposited on: 14 July 2021

Enlighten - Research publications by members of the University of Glasgow http://eprints.gla.ac.uk 


\section{Learning with the Devil: Mentoring and Advocates}

\section{Structured Abstract}

Purpose: The purpose of this research was to understand the lived experience of mentoring to provide insight for those who manage and experience mentoring at work. Research Design: Semi-structured interviews with a cohort of forty-three mentors and their mentees plus key informants. It is a longitudinal qualitative study undertaken with a year's cohort of mentors (referred to as "devil masters") and mentees ("devils") in the profession of law, amongst Scottish barristers, advocates.

Findings: The meanings of mentoring differed widely between individuals. Mentoring relationships differed in their depth, quality and benefits the mentees received. The research findings reveal the inconsistencies and inequalities that are a fundamental part of the experience of mentoring that, as yet the research literature has missed. The research also revealed how mentoring alone was not enough and that structured training was required to supplement mentoring. Further, there is a dependency to be found in mentoring. The mentoring process is power laden.

Originality: As almost all previous research on mentoring is survey based, this is one of the few studies of the lived experience of mentoring, socialisation and cognitive apprenticeship.

Key words: mentoring, law, communities of practice, cognitive apprenticeship

\section{Introduction}


One to one mentoring can be the principal form of learning, development and socialization in professional organizations. This paper presents qualitative longitudinal research to explore the relationships between a cohort of mentors and mentees amongst advocates (Scottish barristers). In this paper one to one mentoring amongst advocates is examined as a principal form of professional socialization, learning, and as a mechanism for entry to the profession. Mentoring has been largely unquestioningly and uncritically accepted as the way to foster learning at work (Hansman, 2002), assumed "a good thing" (Grey, 2001). Some writers appear almost eulogistic about mentoring (Arnold and Johnson, 1997). Mentoring is portrayed as a powerful tool, for example it has been suggested that formal mentoring may be a catalyst for addressing barriers to advancement and developing more diverse leadership (Murrell et al., 2008; Dashper, 2019). Mentoring relationships are advanced as crucial to employee development (Eby and Robertson, 2020). Studies show that those with access to mentoring have been consistently shown to benefit from their involvement in these relationships (Murrell et al., 2008). It is not surprising then that research and interest in mentoring and developmental relationships has steadily increased over the last thirty years (Murphy, 2012). A survey of studies on mentoring finds that there are 124 articles published between 1980 and 2009 alone (Haggard et al., 2011). Mentoring programmes have increased in popularity in the US, UK and globally (Ensher and Murphy, 2010; Ghosh et al., 2019). The Society for Industrial and Organizational Psychology reported that $45 \%$ of their members deliver mentoring programmes (Kulik, 2014). Seventy one per cent of Fortune 500 companies use mentoring to support workplace learning (Giacumo et al., 2020).Yet workplace mentoring is a relatively new focus of study. Methodological concerns have been raised 
such as over reliance on cross-sectional designs and self-report data. Most of the mentoring research is quantitative (Allen et al., 2008). Little research has utilised qualitative methods to examine the lived experience of mentoring. As Kathy Kram notes there is still "a bit of a black box in terms of how relationships unfold in a particular context" (Chandler, 2011).

In the law profession the lived experience of mentoring has received little attention (Kay and Wallace, 2009). Ramaswami et al. (2010) identified just nine studies of mentoring in the law profession published between 1985 and 2006. Since 2006 (using the database ECBSCOhost) a further four have been identified. Of those 13 studies all but one is based in North America and almost all are large quantitative surveys. This dearth of studies into mentoring in law is surprising given how the profession frequently utilises apprenticetype relationships to prepare associates for partnerships over a period of 4-8 years, during articling where graduates of law schools spend 6 months to a year working as articling students, and during preparation for the bar admission examination in the UK and Canada. There is then a need for qualitative research to advance our knowledge and understanding of the everyday experience of mentoring and being mentored.

The aim was to understand the lived experience of mentoring in one specific setting - the profession of Scottish advocates- to shed new light on mentoring relationships, in particular what mentoring meant to both mentors and mentees, how was it understood and experienced, and discuss the challenges. The following questions were asked: How is mentoring understood by the participants in this specific research setting? What are the 
expectations and the perceived outcomes for both the mentor and mentees? What are the key challenges?

\section{Mentoring - definitions and evaluations}

Mentoring has been defined as "off-line help from one person to another in making significant transition in knowledge, work or thinking” (Megginson and Clutterbuck, 1995:13). It usually involves a relationship between an older, more experienced mentor and a younger, less experienced protégé for the purpose of helping develop the protégé's career. However, the term can have many and varied meanings (Kram, 1985). Being a mentor can overlap with other development relationships such as role model, teacher, coach, advisor or supervisor. Haggard et al. (2011) identified approximately 40 different definitions of mentoring and their slight variations. As there is little agreement on how the concept should be defined, it is defined and researched in different ways. These differing definitions are then reflected in research findings, for example the wide range in the percentage of people who self-identify as protégés (33-81\%). The varying definitions and the lack of conceptual clarity of the term create problems in drawing conclusions about mentoring (Burke, 1984). Nevertheless, the research literature identifies attributes of mentoring that provide for a common frame of reference (Eby et al., 2007). First mentoring is portrayed as a learning partnership involving the acquisition of knowledge. It is a process defined by two kinds of support - emotional and instrumental or careerrelated. It is a reciprocal yet asymmetrical relationship where the mentor may benefit but the primary goal is the protégé's growth and development. Finally, the relationship is one which is expected to change over time. 
Studies provide insights into the effectiveness of mentoring. Formal (assigned, planned) mentoring relationships have been found generally to be not as effective as informal relationships which occur spontaneously and are not managed (Ragins and Cotton, 1999; Wanberg et al., 2003), perhaps because informal relationships have developed naturally and voluntarily, without obligation. Ragins and Cotton (1999) found individuals with informal mentors received higher compensation than formally mentored employees. Other studies too have found that informal mentorships provide more benefits than formal relationships do (Chao et al, 1992; Noe, 1998). Those with mentors (whether the relationship is formal or informal) generally have more positive work and career attitudes than those lacking mentors (Allen et al., 2004; Underhill, 2006). Although research shows that self-chosen mentoring relationships are the most valuable and productive, there is a tendency for mentors and protégés to choose partners most like themselves (Hale, 1995). This tendency may prevent the sharing of differing perspectives, limit the learning of both parties and reinforce the status quo. However before considering the dysfunctions, let us look at the functions of and benefits of mentoring.

\section{The functions and benefits of mentoring}

The literature identifies the career, psychosocial and role modelling functions of the mentoring relationship (Scandura, 1992). The career functions include coaching, sponsoring advancement, exposure, fostering positive visibility, protecting protégés from adverse forces and providing challenging assignments. They may also increase the employability of the protégé. The psychosocial functions include counselling, friendship, 
acceptance and confirmation. The role modelling functions are seen as separate and described as where the mentor offers "active" social support (e.g. exchanging confidences) (Scandura, 1992). Mentors may provide some or all these functions and the provision may not only vary from relationship to relationship, but also over time (Ragins, 1997). It is suggested that the greater the number of functions provided by the mentor, the more beneficial the relationship will be for the protégé (Kram, 1985). Also, the more developmental assistance a mentee receives potentially from a constellation of developmental relationships, the greater their work satisfaction (Higgins, 2000; Higgins and Kram, 2001).

The benefits of mentoring found in the literature include increased job and career satisfaction (Wallace, 2001) higher pay and more promotions for protégés (Eby et al., 2008; Kay et al., 2009; Lapointe and Vandenberghe, 2017). Mentoring offers mentees a sense of career security and allows them to feel that their careers are being effectively directed (Higgins, 2000). This gives rise to increased career commitment (Applebaum et al., 1994) positive work attitudes (Lankau and Scandura, 2002) as well as career advancement (Scandura and Pellegrini, 2007). Mentors too learn from mentoring (Hale, 2000) and can acquire valuable work-related information (Kram, 1985). They can gain respect as well as status from a high performing protégé (Feeney and Bozeman, 2008).

\section{Dysfunctional, negative or abusive mentoring relationships}

While the benefits of mentoring tend to be stressed in the literature, it is also acknowledged that there may be problems in the relationships. There is a fairly extensive 
literature on negative, ineffective and dysfunctional mentoring (e.g. Eby et al., 2000; 2008; Cohen and Steele, 2002; Hansford et al., 2004; Simon and Eby, 2003; Ragins et al., 2000; Gosh et al., 2011; Hamlin and Sage, 2011). Relationships may be characterised by overdependence, discontent, anger, jealousy, resentment, sabotage, deception or harassment (Scandura and Williams, 2002). Negative mentor behaviour occurs when mentors overwork their mentees and take credit for the accomplishments, spend more time in impression management and self-promotion (Eby et al., 2000; Eby and Allen, 2002). Additional aggravating factors include the perception of sexual innuendos, rumours, overprotection and paternalism (Eby et al. 2000; Kochan, 2002). There is a fine line between the mentoring relationship being positive, empathetic and dynamic and the relationship becoming compromised by developing into a sexual or romantic one (Morgan and Davidson, 2008). It is suggested that it is good practice for participants in mentoring relationships to be made aware of the risks of sexual or romantic attachments. There are then clear challenges that mentors and mentees face. Perhaps then we should not be surprised by one qualitative study that found that a third of respondents described the upside of not having a mentor (Tolar, 2012).

\section{Power in mentoring}

Mentoring processes and outcomes are power laden (Mott 2002). Inevitably there will be power differences between the mentor and mentee (Eby and Robertson, 2020). While there may be reciprocity, there is not necessarily symmetry in the relationship. Mentoring involves two kinds of influence: one internal to the relationship that focuses on interpersonal influence and the other external to the relationship that involves the 
development of power within the organization. Mentors may help protégés recognise the importance of developing power resources and can provide training in political skills and influence strategies. By providing challenging assignments and placing protégés in visible positions, mentors help develop expert power and visibility. Mentors also provide “reflected power" to their protégés; the mentor's organizational influence augments the protégé's influence and the mentor's power allows them to provide resources for their protégés and buffer their protégés from adverse organizational forces (Kanter 1989). Senior more powerful male mentors have been associated with higher career attainment, particularly for females (Ramaswami et al., 2010; Noonan and Corcoran, 2004). The mentor can also gain power from the relationship. Critical approaches to mentoring in research are still relatively rare, and power relations need to be acknowledged and foregrounded in research (Darwin, 2000).

\section{Gaps in the research on mentoring}

There are only a handful of studies empirically investigating mentoring in the law profession and no qualitative studies in law on the experience of mentoring and being mentored. Research has also almost exclusively focused on the mentor's role in the development of the relationship, rather than it being seen as a reciprocal relationship (Ragins, 1997). It is necessary to examine the personal learning, skill development, identity growth and personal adaptability both from the protégé and mentor perspectives (Higgins and Kram, 2001) and to ask is it really a two-way relationship? There is also little research that has looked at the key challenges faced by mentors and mentees, for example how equity of benefits for protégés can be achieved. People who serve as 
mentors may primarily be members of the dominant of hegemonic groups within organizations or institutions. Potential protégés who are "other" may experience difficulties initiating and participating in mentoring relationships (Sander, 2006; PaynePikus et al., 2010). Issues of power and interests within the organization may hamper the mutual attraction that is required to participate in a mentoring relationship (Hansman, 2000). Formal mentoring programmes have failed to remove barriers to advancement for marginalized groups (Thomas, 2001) yet little research has acknowledged or looked at the issue of power in mentoring. Most of the research on mentoring has been done at a distance, through postal questionnaires. Some qualitative research on mentoring has been completed (e.g. Allen et al., 1997; Eby and Lockwood, 2005; Eller et al., 2014;Jackson et al., 2003; Kram, 1985; Staus et al., 2013; Tolar, 2012) but more qualitative studies are needed to give a more holistic and in-depth understanding of mentoring relations (Scandura and Pellegrini, 2007), how knowledge is transmitted, managed and mentees socialised. Also there are a limited number of studies of formal mentoring in practice (Allen et al., 2006). Few mentoring studies collect data over time (Carter and YussefMorgan, 2019; Banerjee Batist et al., 2018). There is a need then for qualitative longitudinal research looking at the experience of formal mentoring from the perspective of both mentor and mentee which is missing from the literature.

\section{Communities of practice and cognitive apprenticeships}

Following Noonan et al. (2007) the conceptual framework for this study is based on two theoretical perspectives grounded in Vgotsky's (1978) socio-cultural constructivism: cognitive apprenticeship and communities of practice. Both involve supporting an 
individual to become an insider. The objective of a cognitive apprenticeship is to initiate the novice into a community of expert practice (Collins et al. 1989) which requires knowledge transfer. In this context it could be argued that there are two types of knowledge - firstly explicit which is expressed in the formal and systematic language of law that is learned and transmitted, and secondly tacit knowledge which is deeply rooted in action, procedures, routines, values and emotions. Both types are essential to knowledge creation and it will be argued here, institutional maintenance. In this cognitive apprenticeship tacit knowledge is made explicit "crystallised" (Nonaka et al 2000) allowing it to be shared. Socialisation occurs when the mentees learn the tacit knowledge of law through their learning and practical experience. Socialisation also occurs within the social network, the community of advocates that helps the novice learn the language, the norms and belief systems. In turn this initiation promotes the process of enculturation into the discipline. Apprenticeship and coaching begin by modelling and scaffolding providing the greatest support for protégés as they enter into activities within the professional community of advocates. As apprentices increase in self-confidence, they move into a more autonomous phase of collaborative learning, begin to learn how to navigate the culture (Satter and Russ, 2007) and participate more fully in it.

A community of practice (Lave and Wenger, 1991) is a particularly useful framework for analysis of the process of becoming an advocate for two reasons. Firstly, this model of learning is primarily based on informal immersion in practice, shifting the focus away from formal classroom training to informal learning in natural settings. Secondly, the themes emerging from the empirical data from the study of the effectiveness of advocate learning 
strongly resonate with the community of practice model and its emphasis on identity formation as a gradual process.

Communities of practice have been defined as 'a set of relations among persons, activity and world, over time and in relation with other tangential and overlapping communities of practice' (Lave and Wenger 1991: 98) although the term has never been defined precisely (Cox, 2004). The main difference between the cognitive apprenticeship model and the communities of practice is the notion of the master. As in traditional apprenticeship, in a cognitive apprenticeship the learner works under a master teacher who models behavior in a real-life context.

Devilling refers to the period of training, pupillage or junior work undertaken by a person wishing to become an advocate in one of the legal systems of the United Kingdom or Ireland. The devilling relationship under investigation in this study is a composite of both models discussed above - it is highly situated in practice; it involves the process of socialization into the norms and beliefs of the group, and it relies on gradual transition from the periphery to the core of the community. With its emphasis on one master (the devilmaster) in the mentoring relationship, it is closer to the cognitive apprenticeship model. However, as we will argue later, devilling also involves learning from other people in the profession, other advocates and fellow devils in addition to the devilmaster, hence the collective model of communities of practice is crucial to the relationship and the title "learning with the devil". 
Lave and Wenger acknowledge that the concept of community of practice is undeveloped and largely left as "an intuitive notion" (Lave and Wenger, 1991:42.). The theoretical discussion is not followed through in examples of the less than benign effects that can be associated with communities of practice. The communities of practice they examine to illustrate and support their theory are not representative of contemporary workplaces (Rainbird et al., 2001). Lave and Wenger do not acknowledge that learners not only learn in a community, but by watching other learners learn (Mayes, 2002). Also, as Jewson (2007) notes, the term "community" carries connotations of harmony and unity; Lave and Wenger have uncritically drawn on the concept of community as a "symbolically constructed sense of belongingness" (2007:70). In addition, they do not investigate issues of power (Fuller et al., 2004).

\section{Research setting}

In this research setting based at the Scottish bar (the Faculty of Advocates) trainee advocates are called "devils" and those who mentor are referred to as "devilmasters". Each devil has been trained and experienced as a lawyer or solicitor and resigns from their employment to start devilling. Each devilmaster is an Advocate, a specialist in the art of advocacy, representing clients in the superior courts of Scotland when instructed by solicitors. Advocates are sole practitioners who work independently from each other and can only accept instructions through a solicitor or other professional recognised by their professional body, the Faculty of Advocates. 
Devilling lasts about nine months. Of this about three months are formal classroom training which includes interaction with a great number of established members of the advocate community, and a series of assessments. The remaining time is spent with the devilmaster. The devilmaster should, in normal circumstances, be at least seven years qualified as an advocate before being considered eligible to take a devil. No payment is made by the devil for any part of the training or assessment. The devilmaster is not paid to take on a devil and the devil may not be paid for any work that they do. Prior to devilling the prospective devil asks an advocate if he or she is prepared to take the devil on. The principal devilmaster has to be a practitioner predominately in civil law and a devil is mentored for about six months. The devil is also usually assigned a secondary devil master in criminal law for a shorter period of time, usually a maximum of six weeks. Devils are expected to attend court with their devilmasters, to attend consultations with solicitors instructing their devilmaster and with the solicitors' clients. A devil will also discuss the preparation and presentation of the cases in which their devilmaster is involved and will be required to draft written pleadings and opinions. A devilmaster is required to "sign off" a devil confirming they are ready to become a practicing advocate and a member of the Faculty of Advocates.

\section{Research Methods and Analysis}

The study involved 43 semi-structured interviews with mentors, mentees and those who were responsible for the mentoring and training of mentees. All the mentees and their mentors were interviewed so saturation level was reached (Suddaby, 2006). Table 1 lists 
the numbers in each group interviewed and transcript hours. Each interview lasted approximately one hour. The managers of the mentoring and training were interviewed to provide a better understanding of the context of the research and issues surrounding mentoring. A longitudinal study of mentoring was undertaken with a year's cohort of 12 mentees at two points of time - at the start of their training and after a 3-6 month period following admission to the Bar. Before being mentored, the mentees were interviewed; they were asked about what they expected from mentoring. They were then asked a series of questions about their mentoring experience six months later. Mentors were also interviewed which allowed a comparison of the definitions, experiences, challenges and expectations of mentoring. The interviews were conducted by two researchers using the same interview schedule. Of the twelve mentees, the majority were male and three female. Of the mentors, three were female. As few studies compare equal numbers of male and female mentors and protégés (Young et al., 2006) an attempt was made to recruit an equal number of females and male mentors for interview but was unsuccessful. Each interviewee was assured of confidentiality at the start of the interview. Each interview was recorded and transcribed. Each transcript was checked against the recorded interview. This also helped the researchers familiarise themselves with the data. Each respondent was allocated a code with a letter and a number (Mentees D1-12 and Mentors M1-10). Forty-seven hours of interviews were recorded, transcribed and analysed by two researchers. Following Miles and Huberman (1994) we engaged in iterative reading and re-reading of the data and the literature. The data was coded searching for themes. We organized the data under theme headings such as meaning of mentoring and what menteees were expected to do. We linked the themes emerging from the data to general 
constructs that emerged from the literature, e.g. dysfunctions in mentoring and whether mentoring was seen as a two way relationship. Main findings and important illustrative quotes were copied into separate tables for mentors and mentees. Tables of results were compiled to make easy the comparison between individuals within the group and to compare mentors with mentees.

\section{Research findings}

Varied meanings of mentoring

Given the variety of definitions to be found in the literature on mentoring, it is not surprising that meanings of mentoring varied widely between individuals; there was also a lack of conceptual clarity and consistency among the interviewees. We found that devilling was being described as mentoring, as a learning partnership involving the acquisition of knowledge. It provided emotional and career-related support. Yet there were differences between interviewees. For example, some of the devilmasters wanted to debate whether devilling was mentoring, two arguing that it was more like "shadowing". Learning comes about by watching and emulating. Others argued that terms such as "apprenticeship" or "friendship" were more appropriate given that in some cases the relationship between the devil and the devilmaster continues throughout their professional life.

Variable outcomes, experience of mentoring, and the cognitive apprenticeship. 
Relationships between mentors and mentees clearly differed in their depth, quality and the benefits the mentee received. The relationships differed too in how much responsibility the devilmasters were prepared to give the devil. The devilmasters also differed in the ways they approached their role with regards to training, education, teaching, advising, assisting, supporting, shadowing, inspiring, passing on knowledge, professional practice, business acumen. Only two of the devilmasters discussed the twoway nature of the relationship in their definitions of mentoring.

The variability was also caused by the fact that it was found that there was that there was "no one best way" to practice advocacy. Devilmasters gave the mentees the opportunity to see different ways in which jobs could be done, such as conducting a consultation with a client or drafting written pleadings. Each mentor would have "pet theories of good advocacy" (D2) and two mentors could have views which were polar opposites. Two mentors could also hold different expectations of their devil's behaviour. For example, while one mentor expected their devil to remain silent at meetings with solicitors unless specifically requested not to (M3) another encouraged their devil to speak in consultations with solicitors in order "to develop confidence and informality" (M5).

The process of learning the "art of advocacy" through mentoring involved observing, appreciating differences and making choices on how they would practice. The learning process also gained by witnessing other people's and their own mistakes. Some of the tacit knowledge acquisition involved learning the rules of professional conduct, ethics, 
and traditions. For example devils are taught not to call themselves advocates or wear a wig and gown. They have to learn rules that demarcates space in the Faulty Library as they are only permitted to sit in seats reserved for them at just two tables. Other legal professionals, such as solicitors are not permitted to use the library or its facilities, which is symbolic of their lower status. Certain duties in court are reserved for advocates which helps maintain the institution. Devils are told that they should be watching their devil masters and others practice advocacy. They needed to learn how to act, perform or present themselves as an advocate in court. Critical reflection of others and self-reflection on performance was encouraged. They learned in part, as Mayes (2002) argues, by watching others learn. Not surprisingly sometimes theatrical metaphors were used to describe the process. For example, criminal trials are "to some extent theatre" (D3). However, presentation of facts was key.

The research findings also illustrated that the experience of being a devil and expectations of a devilmaster of their devils and the work they were expected to do varied hugely. The work experience varied depending on whether your devilmaster was a criminal or civil one. If your devilmaster specialised in civil law you would be given work to do, such as drafting pleadings or doing library research. If your devilmaster specialised in criminal law then you would be either in court or visiting clients. For those given written work, at one end of the spectrum there would be mentors who would expect their mentees to take responsibility for a piece of work, would review and revise it and then send it out as their own. In contrast, at the other end, there would be those who would only expect their devils to watch and learn, would not give their devils 
responsibility and if the devil did any written work it would "never see the light of day" (M1) though they would receive feedback on it. Some devilmasters would mark and correct the work whereas others would simply discuss it with the devils. In meetings with clients or solicitors they would expect their devil to sit quietly, and just listen, not make any contribution (M1). This was important because they are not being paid and they are not employed to do a job. In another case the mentor argued "If there is an anxious client the last thing the anxious client is going to want is hearing from someone who's not really being paid for their advice" (M9). In between there would be devilmasters who would expect their devils to do the same piece of written work, such as written pleadings, independently, then exchange drafts before comparing notes on how they had both completed their work (M4). Another might expect their devil to work as a shadow, do work "that I have already done myself"(M6). Some would allow their devils to contribute with their opinions, if asked, in consultations with clients and solicitors (e.g. M10). When it came to finding instructions, work for their devils, the majority did not consider this to be their responsibility but in one interview with a devil (D5) it became clear that his devilmaster had told him that it was "part of his role" to make sure he had work on the day he started work as an advocate.

Devilmasters were required to teach their devils the "secrets" of being an advocate which appeared to be about passing on conventions on etiquette and what was considered in this environment to be "good manners" (M9). However, two devilmasters could offer contradictory advice. For example, contradictory advice was given on whether advocates 
were expected to shake hands with other advocates as there had been a convention that Faculty members do not shake hands with each other.

More substantive knowledge is conveyed when devilmasters pass on their knowledge of how best to present a case or a set of pleadings. They also may advise on issues such as how to dress, much of which is prescribed but some choices of dress are about style and taste. Once the trainees have passed the course and process of mentoring, the advocacy training is rounded off with a ceremony. This ceremony takes them over the boundary from being a trainee to becoming an advocate, takes them from the periphery into being considered a full member of the community of practice. In return for the training and support offered by the devilmaster there were a set of expectations of the devil. Mentors talked of expecting certain standards of behaviour.

The two-way relationship?

While the definition of mentoring discusses how it is a two-way relationship, the emphasis, naturally in this environment where mentoring is a compulsory element of the training, was on the devilmaster imparting knowledge to the devil. It was a rare devilmaster who discussed what they gained from their devil in terms stronger than having someone to discuss cases with. However one devilmaster did say, early on in her interview that one of the outcomes she would like to see for the mentoring was "I want to feel I've developed a relationship with them that you know I can go and discuss things with them too, do building that kind of generational Bar relationship" (M11). She liked to learn how they thought about criminal problems from a different perspective and would ask to see written analysis of criminal problems, particularly appeal problems. However, 
it could not be argued that this constituted a relationship in which mutual development and learning took place.

Contradictions and Inconsistencies.

There were inherent contradictions in the mentoring relationships. On the one hand each mentoring relationship is unique. The devilmasters had different styles, techniques and expectations. However, the mentoring relationship should provide the same or similar outcomes for each mentee. There was a lack of consistency in what the devils learned and experienced so a key challenge facing this mentoring scheme was one of equality, control and consistency. The formal training course, providing all trainees with the same knowledge, experience and training, helped counterbalance the inevitable difference in individual experience of devilling. On balance, the formal training course was seen as more effective than one-to-one mentoring. All twelve mentees argued that mentoring on its own would not be viewed as effective. The relational network, as Lave and Wenger predict, is key.

Overwhelmingly the experiences of most participants were positive, because they found that the relationship offered a very positive supportive learning environment. Participants commented on the activities in which they engaged that made devilling a good learning experience, and on the interpersonal qualities of their devilmasters, which assisted the process of learning. Almost all the mentors talked about the mentoring relationship continuing long after the training period. The mentor would be available to answer questions and discuss difficult issues of law or ethics. Some of the mentoring relationships appeared to have worked particularly well and strong bonds developed. In 
these cases, the mentees and mentors were talked of as if they were family, "Faculty family". Devilmasters would introduce their devils to those who had been their devilmasters and to previous devils.

\section{Class and Privilege}

However not all trainees felt part of the "family" or "club". One devil talked of how she did not feel part of it. One reason she gave was that she had not attended a private school (D5). We asked respondents about their social background and discovered that of the ones we had interviewed, only two of the ten devilmasters had been educated in the private sector at both primary and secondary level while one had been experienced private secondary education only. The rest were state educated. Class and privilege was a topic that received more discussion as respondents could see how it might influence how well devils and devilmasters were "matched" (D1). Two devils discussed how those with "rough accents" (D10) or "coarse outlooks" (D6) might not get on so well in the profession. However, the greater issue was one of being able to afford to be unemployed and without any income for a year while they trained to be an advocate. As one of the mentors described: "You have nine months of not being allowed to work, then a period of trying to get work and then a further period of having to wait until you get work" (M5). This lack of income would put off those from poorer backgrounds coming into the profession (D7 and D10).

The dysfunctional relationships The majority of mentoring relationships were reported to work well. However mentoring relationships sometimes were ineffective. This happened in a few cases, for example 
when the mentor and mentee did not get on with each other, where communication between them was poor or they had mismatched expectations of each other. In one case a devilmaster (M1) talked of a relationship where a male mentor thought that their female mentee should know more than she did. In other cases, the devilmaster might not have enough work to do, so they do not give enough work to their mentees. Sometimes mentors protected their mentees publicly and had been seen to compromise their objectivity. One mentor (M4) thought that devils should only have one devilmaster but some had up to four or five which to him "diluted" the experience and the "personal bond". In those cases, the relationships had not been very effective, in his view.

Most of the mentors talked about meeting the devils beforehand to see if they would get along well together. They had clear expectations of the kind of person who they would get along best with. The devils too had clear views. While they would be obliged to select a devilmaster with the appropriate expertise, they would also articulate other criteria. For example, one devil talked of selecting her criminal devilmaster because she was "an excellent speaker" and appeared to be highly "respected by the bench" (D5).

One of the tensions inherent in the relationship between devilmaster and devil was that the devilmaster was teaching their future competitor. In nine months, when the devil is "called" they may be acquiring the instructions that could have gone to their devilmaster. It could be argued that the devilmaster's best interests are served by not engaging in the mentoring process at all and not recommending their devil for work. However, they do it as they have 
an interest in maintaining Faculty, its excellence, its collegiality, the importance of being able to discuss cases with each other and debate points of law, and its traditions.

\section{Discussion and Conclusion}

Our qualitative research aimed to examine the lived experience of mentoring, to open up the "black box" (Chandler, 2011) to shed new light on mentoring relationships. In this paper it is argued that mentoring plays a key role in knowledge acquisition, socialisation and the successful career development of advocates. In this case it is compulsory and so it could be argued that it is formal mentoring. Yet the relationship is also one that is chosen by both parties. Each relationship between a devil and their devilmaster will be a unique relationship. It is a learning partnership that mainly benefits the devil and involves the acquisition of knowledge. The objective of this cognitive apprenticeship is to initiate and socialise the novice into a particular type of community of expert practice, advocacy. This research has demonstrated the lived experience of how the individual mentoring, coupled with the formal training and the social network within the community of advocates helps the novice learn the language, imitate behaviour, gradually start to act in accordance with the norms, rules and belief systems that promotes the process of enculturation into the discipline. It also helps both sustain and maintain the institution of advocacy. This community of practice is an effective arena for solving problems as the devils know whom to ask for help. It is also effective in sharing and spreading best practice, fostering professional development for both protégés and mentors. Mentoring may be crucial. However on its own it is not enough. Structured training is required to supplement mentoring, a finding that the conceptual framework did not help us predict. 
This may prove to be an important research finding or conclusion for other mentoring schemes in law or other professions.

Individuals will differ in how they view and discuss mentoring. However, this research has shown that mentees also differ in terms of their access to social capital, their participation, and potentially their ability to gain from their mentor as well as the network of social relationships. This is something that the community of practice literature tends to ignore. It has been argued here that the mentoring process is power laden. Power and power differences between mentees due to their differing social capital and networks clearly need to be considered by research on mentoring more widely so that unequal relations of power are addressed. It may be that the focus of the organizational learning needs to be on enabling networks and social relationships to broaden and develop for those with less power (Roan and Rooney, 2006). Power differences between the devilmaster and devil are evident in this setting as are differences between devils. What makes this devilling experience different from others outside the profession is that there is a dependency in mentoring. The devil depends on the devilmaster to pay their expenses if required to travel out of town. If the relationship does not develop or breaks down, a good deal is at stake, particularly as the devil may refuse to "sign off" the devil so they can qualify as an advocate. While this may be a perceived threat, it has been shown to be unlikely to happen in practice.

The meanings of mentoring differed as did the experiences of individuals. The outcomes of learning were much more nuanced and individualistic than previous research would have 
led us to believe because individual views and experiences of mentoring differed. There is a tension or contradiction between the unique mentoring relationships that develop and the need for the same learning experience to be delivered to all mentees. Inevitably some mentees will develop and benefit hugely from informal, natural, high quality mentoring relationships while others will be less successful. The profession has historically responded to the inherent weaknesses in mentoring system of learning through the development of the formal classroom training programme and by shifting towards a more dispersed or distributed model of learning, allowing for a broader range of sources of learning. This model is more robust, than mentoring on its own and perhaps other organizations who promote mentoring may like to consider how diffuse the learning is, how many sources of mentee learning are provided. Previous research on mentoring in law in the US has shown how composition and quality of an individual's constellation of developmental relationships accounts for the long run career outcomes such as promotion and work satisfaction for the mentee (Higgins, 2000). Learning in this more diffuse way, within the community of practice, is important and can help alleviate or guard against the dangers of the dysfunctional, negative or abusive relationship that may develop in the reliance on just one mentor for learning and development. However, inherent in the current mentoring system in this organization and elsewhere are key challenges in terms of ensuring equality. Differences can clearly emerge and are likely to be influenced by mentor, power, gender, class and race. Inequalities of power will shape the relationships within the community of practice and should be fore-grounded in research.

Acknowledgement 
Fiona Wilson would like to acknowledge the work of Sabina Siebert in gaining access and collection of data for this research.

\section{References:}

Allen, T.D., Poteet, M.L., and Burroughs, S.M. (1997) The mentor's perspective: a qualitative inquiry and future research agenda, Journal of Vocational Behavior, 51, 7089.

Allen, T.D., Eby. L.T., Poteet, M.L., Lentz, E. and Lima, L. (2004) Career benefits associated with mentoring for protégés: a meta analysis, Journal of Applied Psychology, $89,127-136$.

Allen, T.D. Eby, L.t., and Lentz, E. (2006) The relationship between formal mentoring programme characteristics and perceived programme effectiveness, Personnel Psychology, 59, 125-153.

Allen, T. D., Eby, L. T., O’Brien, K. E., \& Lentz, E. (2008). The state of mentoring research: A qualitative review of current research methods and future research implications. Journal of Vocational Behavior, 73(3), 343-357. Applebaum, S.H., Ritchie, S. and Shapiro, T. (1994) Mentoring revisited: an organizational behaviour construct, Journal of Management Development, 13, 4, 62-72. Arnold, J. and Johnson, K. (1997) Mentoring in early career, Human Resource Management Journal, 7, 4, 61-70. 
Banerjee-Batist, R., Geio, T.G. and Rocco, T.S. (2018) Mentor functions and outcomes: an integrative literature review of sociocultural factors and individual differences, Human Resource Development Review, 18, 1, 114-162.

Burke, R.J. (1984) Mentors in organizations, Group and Organization Studies, 9, 353372.

Burk, H. G., \& Eby, L. T. (2010). What keeps people in mentoring relationships when bad things happen? A field study from the protégé's perspective. Journal of Vocational Behavior, 77(3), 437-446.

Carter, J.W. and Youssef-Morgan, C.M. (2019) The positive psychology of mentoring: a longitudinal analysis of psychological capital development and performance in a formal mentoing program, Human Resource Development Quarterly, 30,3,383-405.

Chao, G.T., Waltz, P.M., and Gardner, P.D. (1992) Formal and informal mentorships: a comparison of mentoring functions and contrast with non-mentored counterparts, Personnel Psychology, 45, 619-636.

Chandler, D.E. (2011) The Maven of Mentoring Speaks: Kathy E. Kram reflects on her career in the field, Journal of Management Inquiry, 20, 1, 24-33.

Cohen, G. L., \& Steele, C. M. (2002). A barrier of mistrust: How negative stereotypes affect cross-race mentoring. Improving academic achievement: Impact of psychological factors on education, 303-327.

Collins, A., Brown, J.S. and Newman, S. (1989) Cognitive apprenticeship: teaching the craft of reading, writing and mathematics in L.B. Resnick (ed.) Knowing, learning and instruction: essays in honor of Robert Glaser (pp.453-494) Hillsdale, NJ: Lawrence Erlbaum Associates. 
Cox, A. (2004) What are communities of practice? A critical review of four seminal works. Paper presented at the Fifth European Conference on Organizational Knowledge, Learning, and Capabilities, $2^{\text {nd }}$ April. Found at http://www.citeulike.org/user/xckuk/article/310649

Darwin, A. (2000) Critical reflections on mentoring in work settings, Adult Education Quarterly, 50, 3, 197-211.

Dashper, K. (2019) Challenging the gendered rhetoric of success? The limitations of women-only mentoring for tackling gender inequality in the workplace, Gender, Work and Organization, 26, 541-557.

Eby, L.T. (2007) Understanding relationship problems in mentoring in B.R. Ragins and K.E. Kram (eds.) The handbook of mentoring at work: theory research and practice, Thousand Oaks, Cal.: Sage.

Eby, L. T., McManus, S. E., Simon, S. A., \& Russell, J. E. (2000). The protege's perspective regarding negative mentoring experiences: The development of a taxonomy. Journal of Vocational Behavior, 57(1), 1-21.

Eby, L. T., \& Lockwood, A. (2005). Protégés' and mentors' reactions to participating in formal mentoring programs: A qualitative investigation. Journal of Vocational Behavior, 67(3), 441-458.

Eby, L. T., \& McManus, S. E. (2004). The protégé's role in negative mentoring experiences. Journal of Vocational Behavior, 65(2), 255-275.

Eby, L.T. and Robertson, M.M. (2020) The psychology of workplace mentoring relationships, Annual Review of Organizational Psychology and Organizational Behavior, 7, 75-100. 
Eby, L.T, McManus, S.E., Simon, S.A. and Russell, J.E (2000) The protégés perspective regarding negative mentoring experiences: the development of a taxonomy, Journal of Vocational Behaviour, 57, 1-21.

Eby, L.T., Rhodes, J.E. and Allen, T.D. (2007) Definition and evolution of mentoring, Chapter 2 in The Blackwell Handbook of Mentoring, E.D. Allen and L.T. Eby (eds.) Oxford: Blackwell Publishing.

Eby, L. T., Durley, J. R., Evans, S. C., \& Ragins, B. R. (2008). Mentors' perceptions of negative mentoring experiences: scale development and nomological validation, Journal of Applied Psychology, 93(2), 358.Eby, L.T., Allen, T.D., Evans, S.C., NG, T and DuBois, D. (2008) Does mentoring matter? A multidisciplinary meta-analysis comparing mentored and non-mentored individuals, Journal of Vocational Behaviour, 72, 254-267. Eller, L.S., Lev, E.L., Feurer, A. (2014) Key components of an effective mentoring relationship: a qualitative study, Nurse Education Today, 34, 5, 815-820. Ensher, E.A. and Murphy, S.E. (2010) The Mentoring Relationship Challenges Scale: the impact of mentoring stage, type and gender, Journal of Vocational Behaviour, 79, 253266.

Feeney, M.K. and Bozeman, B. (2008) Mentoring and network ties, Human Relations, $61,1651-1676$.

Fuller, A., Hodkinson, H., Hodkinson, P. and Unwin, L. (2004) Learning as peripheral participation in communities of practice: a reassessment of key concepts in workplace learning, British Educational Research Journal, 31, 1, 49-68. 
Ghosh, R., Dierkes, S., \& Falletta, S. (2011). Incivility spiral in mentoring relationships: reconceptualizing negative mentoring as deviant workplace behaviour, Advances in Developing Human Resources, 13(1), 22-39.

Ghosh, R., Shuck, B., Cumberland, D., and D’Mello, J. (2019) Building Psychological Capital and Employee Engagement: is formal mentoring a useful human resource development intervention? Performance Improvement Quarterly, 32, 1, 37-54. Giacumo, L.A., Chen, J. and Cruz, A. S. (2020) Evidence of the use of mentoring programs and practices to support workplace learning: a systematic multiple studies review, Performance Improvement Quarterly, 33, 3, 259-303.

Grey, C. (2001) Against learning, Research papers in Management Studies, Cambridge: The Judge Institute of Management Studies, Cambridge. Haggard, D.L., Dougherty, T.W., Turban, D.B. and Wilbanks, J.E. (2011) Who is a mentor? A review of evolving definitions and implications for research, Journal of Management, 37, 1, 280-304.

Hamlin, R. G., \& Sage, L. (2011). Behavioural criteria of perceived mentoring effectiveness: An empirical study of effective and ineffective mentor and mentee behaviour within formal mentoring relationships. Journal of European Industrial Training, 35(8), 752-778.

Hale, M.M. (1995) Mentoring women in organizations: practice in search of a theory, American Review of Public Administration, 25, 327-339.

Hale, R. (2000) To match or mismatch? The dynamics of mentoring as a route to personal and organizational learning, Career Development International, 5, 4/5, 223-234. 
Hansford, B.C., Ehrich, L.C. amd Tennent, L. (2004) Formal mentoring programs in education and other professions: a review of the literature, Educational Administration Quarterly, 40, 4, 518-540.

Hansman, C. A. (2000). Formal mentoring programs. In A. L. Wilson \& E. R. Hayes (eds.) Handbook of adult and continuing education (new edition, pp. 493-507). San Francisco: Jossey-Bass.

Hansman, C.A. (2002) Diversity and power in mentoring relationships in Critical perspectives on mentoring: trends and issues, C.A. Hansman (ed.) Office of Educational Research and Improvement, US Department of Education, Washington, DC. Higgins, M.C. (2000) The more, the merrier? Multiple development relationships and satisfaction, Journal of Management Development, 19, 4, 277-296.

Higgins, M.C. and Thomas, D.A. (2001) Constellations and careers: toward understanding the effects of multiple developmental relationships, Journal of Organizational Behaviour, 22, 3, 223-247.

Higgins, M.C. and Kram, K.E. (2001) Reconceptualising mentoring at work: a developmental network perspective, Academy of Management Review, 26, 264-288. Hoffman, E.A. (2007) Legal education and early career mentoring: mid-career attorneys' pro bono commitment, International Journal of the Legal Profession, 14, 1, 81-96. Jackson, V. A., Palepu, A., Szalacha, L., Caswell, C., Carr, P. L., \& Inui, T. (2003). "Having the right chemistry": a qualitative study of mentoring in academic medicine. Academic Medicine, 78(3), 328-334. 
Jewson, N. (2007) Cultivating network analysis; rethinking the concept of "community" within "communities of practice", Chapter 6 in J. Hughes, N. Jewson and L. Unwin (eds). Communities of Practice: critical perspectives, London: Routledge, pp.68-82.

Kanter, R.M. (1989) When giants learn to dance: mastering the challenge of strategy, management and careers in the 1990s, New York Simon and Schuster.

Kay, F.M., Hagan, J. and Parker, P. (2009) Principals in practice: the importance of mentorship in the early stages of career development, Law and Policy, 31, 1, 69-110. Kay, F.M. and Wallace, J.E. (2009) Mentors as social capital: gender, mentors and career rewards in law practice, Sociological Inquiry, 79, 4, 418-452.

Kochan, F. K. (2002). Examining the organizational and human dimensions of mentoring: A textual data analysis. In F. K. Kochan, (Ed.), The organizational and human dimensions of successful mentoring programs and relationships (pp. 269-286). Greenwich, CT: Information Age.

Kram, K. E. (1985) Mentoring at work: developmental relationships in organizational life, Glenview, IL: Scott Foresman.

Kulik, C.T. (2014) Working below and above the line: the research-practice gap in diversity management, Human Resource Management Journal, 24, 2, 129-144.

Lankau, M.J. and Scandura, T.A. (2002) Mentoring and personal learning: content, antecedents and outcomes, Academy of Management Journal, 45, 779-790.

Lapointe, É, and Vandenberghe, C. (2017). Supervisory mentoring and employee affective commitment and turnover: the critical role of contextual factors. Journal of Vocational Behaviour. 98, 98-107

Lave, J. And Wenger, E. (1991) Situated learning: legitimate peripheral participation, Cambridge: Cambridge University Press. 
Mayes, T. (2002) 'The Technology of Learning in a Social World', in R. Harrison, F. Reeve, A. Hanson and J. Clarke (eds.) Supporting Lifelong Learning: Perspectives on Learning, Routledge/Falmer, London, pp. 163-175.

Megginson, D. and Clutterbuck, D. (1995) Mentoring in Action: a practical guide for managers, London: Kogan Page Ltd.

Miles, M.B. and Huberman, A.M. (1994) Qualitative data analysis, Sage, London. Morgan, L.M. and Davidson, M.J. (2008) Sexual dynamics in mentoring relationships - a critical review, British Journal of Management, 19, S120-S129.

Mott V. (2002) Emerging perspectives on mentoring: fostering adult learning and development. In: Hansman C, Mott V, Ellinger A.D., Guy T, editors. Critical Perspectives on Mentoring: Trends and Issues. Eric Info Series No. 388. Ohio, Japan: ERIC Clearinghouse on adult, career, and vocational education, Ohio State University, pp. 15-26.

Murphy, W.M. (2012) Reverse mentoring at work: fostering cross-generational learning and developing millennial leaders, Human Resource Management, 51, 4, 549-574.

Murrell, A.J., Blake-Beard, S., Porter, D.M. and Perkins-Williamson, A. (2008) Interorganizational formal mentoring: breaking the concrete ceiling sometimes requires support from the outside, Human Resource Management, 47, 2, 275-295.

Noe, R.A. (1988) An investigation of the determinants of successful assigned mentoring relationships, Personnel Psychology, 41, 57-479.

Noonan, M.C. and Corcoran, M.E. (2004) The Mommy track and partnership: temporary delay or dead end? The ANNALS of the American Academy of Political and Social Science, 596, 130-150. 
Noonan, M.J.; Ballinger, R. and Black, R. (2007) Peer and faculty mentoring in doctoral education: definitions, experiences and expectations, International Journal of Teaching and Learning in Higher Education, 19, 3, 251-262.

Nonaka, I, Toyama, R and Konno, N. (2000) SECI, Ba and Leadership: a unified model of dynamic knowledge creation, Long Range Planning, 33, 5-34.

Payne-Pikus, M.R., Hagan, J. and Nelson, R. (2010) Experiencing discrimination: race and retention in America's largest law firms, Law and Society Review, 44, 3-4, 553-584. Ragins, B.R. (1997) Diversified mentoring relationships in organizations: a power perspective, The Academy of Management Review, 22, 2, 482-521.

Ragins, B.R. and Cotton, J.L. (1999) Mentor functions and outcomes: a comparison of men and women in formal and informal mentoring relationships, Journal of Applied Psychology, 84, 529-550.

Ragins, B. R., Cotton, J. L., \& Miller, J. S. (2000). Marginal mentoring: The effects of type of mentor, quality of relationship, and program design on work and career attitudes. Academy of Management Journal, 43(6), 1177-1194.

Rainbird, H., Munro, A. and Holly, L. (2001) Between communities of practice and the employment relationship: a perspective from the labour process, International Workshop, University College, Northampton, $8^{\text {th }}-10^{\text {th }}$ November.

Ramaswami, A., Dreher, G.F., Bretz, R. and Wiethoff, C. (2010) The interactive effects of gender and mentoring on career attainment: making the case for female lawyers, Journal of Career Development, 37, 4, 692-716.

Riley, S. and Wrench, D. (1985) Mentoring among women lawyers, Journal of Applied Social Psychology, 15, 4, 374-386. 
Roan, A. and Rooney, D. 92006) Shadowing experiences and the extension of communities of practice: a case study of women education managers, Management Learning, 37, 4, 433-454.

Sander, R.H. (2006) The racial paradox of the corporate law firm, 54 North Carolina Law Review, 755-822.

Satter, A.M. and Russ, D.E. (2007) Why don't more senior leaders mentor? And how they are mortgaging their company's future in the process, Journal of Management Inquiry, 16, 4, 382-390.

Scandura, T.A. (1992) Mentorship and career mobility: an empirical investigation, Journal of Organizational Behaviour, 13, 169-174.

Scandura, T.A. (1998) Dysfunctional Mentoring Relationships and Outcomes, Journal of Management, 24, 3, 449-467.

Scandura, T.A. and Pellegrini, E.K. (2007) Workplace mentoring: theoretical approaches and methodological issues, Chapter 5 in The Blackwell Handbook of Mentoring, E.D. Allen and L.T. Eby (eds.) Oxford: Blackwell Publishing Scandura, T.A. and Williams, E.A.(2002) Formal mentoring: the promise and the precipice in C.L. Cooper and R.J. Burke (eds.) The new world of work: challenges and opportunities, pp. 49-74, Oxford: Blackwell.

Simon, S. A., \& Eby, L. T. (2003). A typology of negative mentoring experiences: A multidimensional scaling study, Human Relations, 56(9), 1083-1106.

Strauss, S.E., Johnson, M.O., Marquez,C. and Feldman, M.D. (2013) Characteristics of successful and failed mentoring relationships: a qualitative study across two academic 
health centres, Academic Medicine: Journal of the Association of American Medical Colleges, 88, 1, 82 .

Suddaby, R. (2006) From the editors: what grounded theory is not, Academy of Management Journal, 49, 633-642.

Tolar, M.H. (2012) Mentoring experiences of high-achieving women, Advances in Developing Human Resources, 14, 2, 172-187.

Thomas, D.A.(2001) The truth about mentoring minorities, race matters, Harvard Business Review, April, 99-107.

Underhill, C.M. (2006) The effectiveness of mentoring programs in corporate settings: a meta-analytical review of the literature, Journal of Vocational Behaviour, 68, 292-307. Vygotsky, L.S. (1978) Mind in Society, (M. Cole, V. John-Steiner, S. Scriber and E. Souberman, trans) Cambridge, MA: Harvard University Press. (Original work published in 1930).

Wallace, J.E. (2001) The benefits of mentoring for female lawyers, Journal of Vocational Behaviour, 58, 366-391.

Wanberg, C.R., Welsh, E.T. and Hezlett, S.A. (2003) Mentoring research: a review and dynamic process model, Research in Personnel and Human Resources Management, 22, $39-124$.

Webley, L. (2010) Gate-keeper, supervisor or mentor? The role of professional bodies in the regulation and professional development of solicitors and family mediators undertaking divorce matters in England and Wales, Journal of Social Welfare and Family Law, 32, 2, 119-133. 
Wenger, E.C. and Synder, W.M. (2000) Communities of practice: the organizational frontier, Harvard Business Review, 78, 1, 139-145.

Wenger, E.C.(1998). Communities of Practice: Learning, Meaning, and Identity.

Cambridge: Cambridge University Press

Young, A.M., Cady, S. and Foxon, M.J. (2006) Demystifying gender differences in mentoring: theoretical perspectives and challenges for future research on gender and mentoring, Human Resource Development Review, 5, 148-175.

Table 1 Semi-structured interviews

\section{Interviewees}

Devils interviewed in the

first month of devilling

Devils interviewed after 3-6

months after admission to

the Faculty

Expert informants

(managers, and key

stakeholders in advocate

education)

Devilmasters

Total
12

Number of interviews

12

5

14

43 interviews
8

Total recording time

(hours)

9

14

16

47 hours 